\title{
Acute Proximal Tubular Necrosis Due to Cidofovir Usage in BK Virus Related Hemorrhagic Cystitis in an Allogeneic Stem Cell Transplanted Patient
} Allojenik Kök Hücre Nakli Yapılan Bir Hastada BK Virüsüne Bağlı Gelişen Hemorajik Sistitte Kullanılan Cidofovire Bağlı Olarak Ortaya Çıkan Akut Proksimal Tübüler Nekroz

\section{Sebnem Izmir Guner ${ }^{1} \mathbb{D}$, Mustafa Teoman $\operatorname{Yanmaz}^{2} \mathbb{D}$, Ekrem Guner $^{3} \mathbb{D}$, Pinar Seymen ${ }^{4} \mathbb{D}$, Melike Nalbant Moray ${ }^{5}$ (D), Isin Kilicaslan $^{5}$ (D)}

\author{
${ }^{1}$ Department of Hematology, Istanbul Gelisim University, Memorial Sisli Hospital Hematology and Bone Marrow Transplantation Center, Istanbul, Turkey \\ ${ }^{2}$ Department of Medical Oncology, Arel University, Memorial Bahcelievler Hospital, Istanbul, Turkey \\ ${ }^{3}$ Department of Urology, University of Health Sciences, Dr. Sadi Konuk Training and Research Hospital, Istanbul, Turkey \\ ${ }^{4}$ Department of Nephrology, Halic University, Medicana Kadikoy Hospital, Istanbul, Turkey \\ ${ }^{5}$ Deparment of Pathology, Istanbul University, Faculty of Medicin, Istanbul, Turkey
}

Cite as: Izmir Guner S, Yanmaz MT, Guner E, Seymen P, Nalbant Moray M, Kilicaslan I. Acute proximal tubular necrosis due to cidofovir usage in BK virus related hemorrhagic cystitis in an allogeneic stem cell transplanted patient. Grand J Urol 2021;1(2):71-4.

Submission date: 27 November 2020

Acceptance date: 03 December 2020

Online first: 10 February 2021

Publication date: 20 May 2021

Corresponding Author: Sebnem Izmir Guner / Department of Hematology, Istanbul Gelisim University, Memorial Sisli Hospital Hematology and Bone Marrow Transplantation Center, Istanbul, Turkey / sebnemizmirguner@gmail.com ORCID ID: 0000-0002-6326-9424

\begin{abstract}
Hemorrhagic cystitis (HS) is a frequently seen complication of bone marrow transplantation. This condition occurs depending on the preparatory regimen of bone marrow transplantation. The BK virus (BKV), a human polyomavirus, is a small double helix DNA virüs belonging to the Papovaviridae family. It is commonly found in societies as an occult infection. Whereas, cidofovir (CDV), an acyclic nucleoside phosphonate, is used as a proven antiviral agent against polyomaviruses. In this case report, acute proximal tubular necrosis due to cidofovir used in hemorrhagic cystitis caused by BK virus, and its treatment in a patient diagnosed with T-lymphoblastic lymphoma in remission, and underwent allogeneic stem cell transplantation, was presented.
\end{abstract}

Keywords: hemorrhagic cystitis, BK virus, T-lymphoblastic lymphoma, acute proximal tubular necrosis

$\ddot{\mathrm{O} z}$

Hemorajik sistit (HS), kemik iliği transplantasyonun sık görülen bir komplikasyonudur. Bu durum, kemik iliğinin hazırlık rejimine bağlı olarak ortaya çıkmaktadır. Bir insan poliomavirüsü olan BK virüsü (BKV), küçük bir çift sarmal DNA virüsüdür. Papovaviridae ailesine ait bir virüsdür. Genellikle toplumlarda latent bir enfeksiyon olarak bulunur. Bunlarla birlikte, bir asiklik nükleosit fosfonat olan cidofovir (CDV), poliomavirüslere karşı kanıtlanmıș bir antiviral ajan olarak kullanılır. Bu olgu sunumunda allojenik kök hücre nakli yapılan remisyondaki T-lenfoblastik lenfoma tanılı hastada BK virüsüne bağlı olarak gelişen hemorajik sistitte kullanılan cidofovirin yapmış olduğu akut proksimal tubuler nekroz ve tedavi yönetimi anlatılmıştır.

Anahtar kelimeler: hemorajik sistit, BK virüs, T-lenfoblastik lenfoma, akut proksimal tübüler nekroz 


\section{Introduction}

The BK virus (BKV), a human polyomavirus, is a small double helix DNA virus belonging to the Papovaviridae family. It is commonly found in societies and forms a latent infection. However, it can lead to serious clinical findings in patients with immunosuppression such as patients who had undergone bone marrow or solid organ transplantation or patients with cancer [1]. Hemorrhagic cystitis (HS) is seen as a frequent complication of bone marrow transplantation. This condition occurs depending on the conditioning regimen of bone marrow transplantation. Hematuria, dysuria, pollakiuria, and suprapubic pain are the most common findings and symptoms of its clinical presentation. Its emergence is not only limited to cases where bone marrow transplantation is performed. It can also occur during the treatment of some other neoplastic diseases where cyclophosphamide (CY) or ifosfamide is used.

Hematuria occurs two weeks after the administration of bone marrow transplantation preparatory regimens where cyclophosphamide (CY) or ifosfamide is used. In contrast, hemorrhagic cystitis has also been reported to occur immediately or in the long term, three months after the administration of cyclophosphamide. Hemorrhagic cystitis (HS) is defined in two groups as early- or late-onset HS, taking into consideration the differences in the etiologies. Early-onset hemorrhagic cystitis is more commonly associated with chemoradiotherapy used in conditioning regimens of bone marrow transplantation. Late-onset hemorrhagic cystitis occurs weeks or months after the transplantation. Multiple factors are accused in the etiology. A previously emerged HS is considered a risk factor in itself for this type of HS. In addition, viruses and Graft-Versus-Host Disease (GVHD) are also accused in the etiology. The major accused viruses are BK virus (BKV), adenovirus and cytomegalovirus [2-5]

The BK virus, which remains latent in renal and uroepithelial cells after primary infection, reactivates after transplantation in which immunosuppressive agents are used and the cellular immunity is weakened [6]. The most common pathology caused by the reactivation of BKV is HS, and supportive therapies such as hyperhydration, alkalinization, and bladder irrigation are usually applied in the treatment. Cidofovir (CDV) which is an acyclic nucleoside phosphonate in antiviral drugs used in the treatment against polyomaviruses has been reported as an agent with confirmed efficiency [7-10] 19 of 71. Cidofovir, a nucleotide analog, exerts its effect by inhibiting viral DNA polymerase and preventing chain elongation. Unlike nucleoside analogs, it contains a phosphatase group. Cidofovir (CDV) is given to patients infected with BKV at a dose of $5 \mathrm{mg} / \mathrm{kg}$ per week during the first 2 weeks. After that, the treatment is repeated every 2 weeks. Its most important side effect is renal failure manifested by proteinuria, which can be prevented by using probenecid [11-13]. Renal failure is the main toxicity of $\mathrm{CDV}$, and therefore serum creatinine and urine protein levels should be measured before each CDV application. To reduce its side effect, CDV should be used with oral probenecid and intravenous physiological saline solution [11-13].

In this case report, the management of acute proximal tubular damage due to the use of cidofovir in hemorrhagic cystitis caused by BK virus in a patient with T-lymphoblastic lymphoma in remission, in whom allogeneic stem cell transplantation was performed, was presented.

\section{Case Presentation}

For a 22-year-old male diagnosed with T-lymphoblastic lymphoma in October 2014, stem cells were collected with cyclophosphamide + G-CSF (granulocyte colony-stimulating factor) regimen under partial response obtained after chemotherapy and radiotherapy, then autologous stem cell transplantation was performed on the patient in December 2015 with BEAM stem cell conditioning regimen. The patient who showed recurrence in the follow-up received the FLAG-IDA chemotherapy protocol; and hematopoietic peripheral stem cells were transplanted from the HLA 9/10 compatible haploidentical unrelated donor in October 2016 using the reduced intensity conditioning (RIC) stem cell conditioning regimen. The patient was suspected of hemorrhagic cystitis infection related to the reactivation of $\mathrm{BKV}$ due to the development of macroscopic hematuria on the 50th day after transplantation. In the urinalysis, BKV: 3, 444.359.614 copy/ml was detected, so the patient was treated with $5 \mathrm{mg} / \mathrm{kg}$ i.v. cidofovir per week, then the treatment continued at 2-week intervals. To protect against renal failure, probenecid was given orally at doses of $1.25 \mathrm{mg} / \mathrm{m}^{2} 3$ hours before and 1 and 8 hours after the administration of CDV. In addition to $\mathrm{CDV}$, cyclosporine treatment was also started for GVHD prophylaxis, and cyclosporine levels and renal functions were followed in the patient once in two days. BKV levels were measured weekly. Since BK virus disappeared in the urine and blood, and hematuria disappeared after 4 doses of CDV, the cyclosporine dose was reduced to $25 \mathrm{mg}$ daily after the 75 th day of stem cell transplantation. Remission was detected in PET/ CT taken on the 90th day after stem cell transplantation. In the patient who reduced the intake of fluids due to nausea and hid it, the blood urea and creatinine levels were $139 \mathrm{mg} / \mathrm{dl}$ and 6.78 $\mathrm{mg} / \mathrm{dl}$, respectively, on the 122th day of stem cell transplantation due to insufficient fluid intake. In the evaluation, the patient with normal anion gap metabolic acidosis was urgently interned and intravenous hydration was started. However, he was hemodialyzed due to the absence of improvement in their values. The patient, whose creatinine level could not be

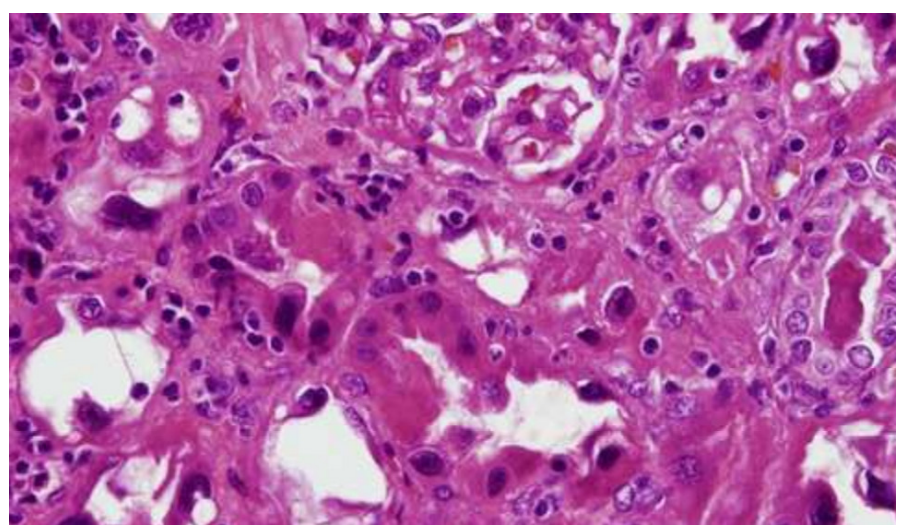

Figure 1. Histopathologic findings of tubular epithelial cell necrosis (renal biopsy specimen) 
reduced despite all the treatments, underwent US-guided kidney biopsy. In the histopathological examination of renal biopsy specimen, nucleomegaly, hyperchromasia, and atypia, as well as, interstitial mixed inflammatory cell infiltration were detected in tubular epithelial cells due to CDV (Figure1). The patient who entered chronic renal failure continued with bicarbonate hemodialysis treatment 2 times a week with the recommendation of nephrology consultation.

\section{Discussion}

After transplantation, the frequency of hemorrhagic cystitis varies between 5-70 percent [4]. In some patients with bone marrow transplantation, asymptomatic microscopic hematuria may be detected clinically. In contrast, a small number of patients have resistant and long-term macroscopic hematuria, dysuria and bladder-induced pain that indicate hemorrhagic cystitis (HS). The diagnosis is usually based on clinical data, and the urinary infection due to other agents should be excluded. For this purpose, the mid-stream urine culture should be made. With cytological examination of urine, abnormally shaped urinary epithelial cells with hyperchromatic nuclei can be seen in one third of the cases. In the presence of BKV, intracellular inclusions stained with Papanicolaou dye may be noted. The presence of BKV can also be revealed by electron microscopy, ELISA or by the demonstration of the genomic structure of the virus. It is not easy to show BKV in the culture media. In our case, the presence of the BK virus in urine was detected by the PCR method.

Renal failure is the main toxicity of CDV, therefore serum creatinine and urine protein levels should be evaluated before each CDV administration. CDV should be used along with oral probenecid and intravenous physiological saline solution. In the present case, in the treatment of hemorrhagic cystitis caused by the BK virus with cidofovir, acute proximal tubular damage developed, and hemodialysis treatment had to be initiated in spite of prophylaxis with probenecid. In this case report, the management of acute proximal tubular damage due to the use of cidofovir in hemorrhagic cystitis caused by BK virus in a patient with T-lymphoblastic lymphoma in remission who underwent allogeneic stem cell transplantation, was presented. Although hemorrhagic cystitis caused by chemotherapy protocol is frequently seen in the preparatory stage of bone marrow transplantation, acute proximal tubular damage and renal failure due to CDV used in the treatment of serious HS cases have attracted attention as a relatively rare complication.

Ethics Committee Approval: N / A.

Informed Consent: An informed consent was obtained from the patient.

Publication: This study was presented in the VIIIth International Eurasian Hematology Oncology Congress on 18-21 October 2017 in Istanbul, Turkey.

Peer-review: Externally peer-reviewed.

Authorship Contributions: Any contribution was not made by any individual not listed as an author. Concept - S.I.G., M.T.Y., E.G.; Design - S.I.G., M.T.Y., E.G.; Supervision - S.I.G., I.K.; Resources - S.I.G., P.S., M.N.M.; Materials - S.I.G., P.S., M.N.M.; Data Collection and/or Processing - S.I.G., E.G., P.S.,
M.N.M.; Analysis and/or Interpretation - S.I.G., E.G., P.S., M.N.M.; Literature Search - P.S., M.N.M.; Writing- S.I.G., M.T.Y., E.G.; Critical Review - S.I.G., I.K.

Conflict of Interest: The authors declare that they have no conflict of interest.

Financial Disclosure: The authors have declared that they did not receive any financial support for the realization of this study.

\section{References}

[1] Siguier M, Sellier P, Bergmann JF. BK-virus infections: A literature review. Med Mal Infect 2012;42:181-7. https://doi.org/10.1016/j.medmal.2012.04.011.

[2] Gargiulo G, Orlando L, Alberani F, Crabu G, Di Maio A, Duranti $\mathrm{L}$, et al. Haemorrhagic cystitis in haematopoietic stem cell transplantation (HSCT): A prospective observational study of incidence and management in HSCT centres within the GITMO network (Gruppo Italiano Trapianto Midollo Osseo). Ecancermedicalscience 2014;8:420.

https://doi.org/10.3332/ecancer.2014.420.

[3] Yang CC, Hurd DD, Douglas Case L, Assimos DG. Hemorrhagic cystitis in bone marrow transplantation. Urology 1994;44:322-8. https://doi.org/10.1016/S0090-4295(94)80085-5.

[4] Yaghobi R, Ramzi M, Dehghani S. The Role of Different Risk Factors in Clinical Presentation of Hemorrhagic Cystitis in Hematopoietic Stem Cell Transplant Recipients. Transplant Proc 2009;41:2900-2. https://doi.org/10.1016/j.transproceed.2009.07.060.

[5] Sencer SF, Haake RJ, Weisdorf DJ. Hemorrhagic cystitis after bone marrow transplantation: Risk factors and complications. Transplantation 1993;56:875-9. https://doi.org/10.1097/00007890-199310000-00020.

[6] Dropulic LK, Jones RJ. Polyomavirus BK infection in blood and marrow transplant recipients. Bone Marrow Transplant 2008;41:11-8. https://doi.org/10.1038/sj.bmt.1705886.

[7] Bedi A, Miller CB, Hanson JL, Goodman S, Ambinder RF, Charache $\mathrm{P}$, et al. Association of BK virus with failure of prophylaxis against hemorrhagic cystitis following bone marrow transplantation. J Clin Oncol 1995;13:1103-9. https://doi.org/10.1200/JCO.1995.13.5.1103.

[8] Raval M, Gulbis A, Bollard C, Leen A, Chemaly R, Shpall E, et al. Evaluation and management of BK virus-associated nephropathy following allogeneic hematopoietic cell transplantation. Biol Blood Marrow Transplant 2011;17:1589-93. https://doi.org/10.1016/j.bbmt.2011.07.010.

[9] Pahari A, Rees L. BK virus-associated renal problemsClinical implications. Pediatr Nephrol 2003;18:743-8. https://doi.org/10.1007/s00467-003-1184-3.

[10] Arthur RR, Shah K V, Baust SJ, Santos GW, Saral R. Association of BK Viruria with Hemorrhagic Cystitis in Recipients of Bone Marrow Transplants. N Engl J Med 1986;315:230-4. https://doi.org/10.1056/nejm198607243150405. 
[11] Farasati NA, Shapiro R, Vats A, Randhawa P. Effect of Leflunomide and Cidofovir on replication of BK virus in an in vitro culture system. Transplantation 2005;79:116-8. https://doi.org/10.1097/01.TP.0000149338.97084.5F.

[12] Vats A, Shapiro R, Randhawa PS, Scantlebury V, Tuzuner A, Saxena M, et al. Quantitative viral load monitoring and cidofovir therapy for the management of BK virus-associated nephropathy in children and adults. Transplantation 2003;75:105-12.

https://doi.org/10.1097/00007890-200301150-00020.
[13] Kadambi P V, Josephson MA, Williams J, Corey L, Jerome KR, Meehan SM, et al. Treatment of refractory BK virusassociated nephropathy with cidofovir. Am J Transplant 2003;3:186-91.

https://doi.org/10.1034/j.1600-6143.2003.30202.x. 